Environmental Research Journal 6(5): 321-328, 2012

ISSN: 1994-5396

(C) Medwell Journals, 2012

\title{
Seasonal Variations of Some Heavy Metals in Water, Sediments and Fish Samples Collected from the River Nile, Egypt
}

\author{
${ }^{1,2}$ A.G.M. Osman, ${ }^{3}$ K. Y. Abuel-Fadl, ${ }^{1}$ A.M. Elbtar and ${ }^{3}$ M.A.M. Taha \\ ${ }^{1}$ Department of Zoology, Faculty of Science, \\ Al-Azhar University (Assiut Branch), 71524 Assiut, Egypt \\ ${ }^{2}$ Department of Ecophysiology and Aquaculture, \\ Leibniz-Institute of Freshwater Ecology and Inland Fisheries, 12587 Berlin, Germany \\ ${ }^{3}$ The Egyptian Environmental Affairs Agency (EEAA), Assiut Branch, Assiut, Egypt
}

\begin{abstract}
The contamination of water, sediments and biota with heavy metals is of important concern because of their toxicity, persistence and bio-accumulative nature. The present researchers was aimed to study the effects of seasons on the concentrations of $\mathrm{Pb}, \mathrm{Cd}, \mathrm{Cu}, \mathrm{Cr}$ and $\mathrm{Fe}$ in water, sediment and freshwater fish (Clarias gariepinus) collected from the whole course of the River Nile form its spring at Aswan to its estuaries at Damietta and Rosetta. Water, sediment and fish samples collected from Damietta and Rosetta sites displayed highest metal concentrations. This was expected due to the fact that the level of contamination is greater downstream River Nile, compared to upstream sampling sites. The highest seasonal mean levels of the selected heavy metals in water and sediment samples were recorded during spring period along the whole course of the River Nile. The lowest ones were recorded during autumn for nearly all heavy metals. The levels of heavy metals in the tissues of the selected fish showed highly significant differences between seasons. According to the result of the present research, seasonal variations of heavy-metal levels in the tissues of African catfish follow sinusoidal curves. The maximum level of most heavy metals was detected during summer which represents the growth period of the African catfish. The minimum level of most metals was recorded during autumn period which corresponds the breeding season of Clarias gariepinus. This confirmed the accumulation of some metals in the gonad tissue which intern eliminated from the tissue during spawning seasons.
\end{abstract}

$\underline{\text { Key words: River Nile, African catfish Clarias gariepinus, heavy metals, seasonal variation, aquatic pollution }}$

\section{INTRODUCTION}

Heavy metals are generally and naturally found at very low concentrations while elevated concentrations are commonly associated with pollution from human activities (Forstner and Wittman, 1981; Idodo-Umeh, 2002). The contamination of freshwater with heavy metals has become a matter of great concern over the last few decades because of the threat to public water supplies, their devastating effects on the ecological balance of the aquatic environment and their damage caused to the aquatic life (Suzuki et al., 1988; Klavins et al., 2000). Total heavy metal concentrations in aquatic components can mirror the present pollution status of these areas (Haiyan and Stuanes, 2003). While some of these heavy metals $(\mathrm{Fe}, \mathrm{Ca}, \mathrm{Cu}$ and $\mathrm{Na}$ ) are essential nutrients that are required in enzymatic biochemical activities in the body, some others like $\mathrm{Cu}, \mathrm{Pb}$ and $\mathrm{Hg}$ are extremely toxic even at low concentrations (Kakulu and Osibanjo, 1988; Fagbemi and Oshodi, 1991). Toxic heavy metals in the aquatic environment get to man either directly from drinking water or indirectly through food chain and have been implicated in many human health conditions (Forstner and Wittman, 1981; Bruins et al., 2000; Hussein et al., 2005). Therefore, monitoring of such metals is important for safety assessment of the environment and human health in particular.

Sediments are important sinks for heavy metals and play a significant role in the remobilization of contaminants in aquatic systems under favourable conditions and in interactions between water and sediments (Asaolu et al., 1997). Monitoring the concentration of heavy metals in the sediment is important since knowledge of the heavy metal levels in sediments gives vital information regarding their sources, distribution and degree of pollution. This is for the fact

Corresponding Author: A.G.M. Osman, Department of Environmental Quality, Egyptian Environmental Affairs Agency, 46 Bany Ghalab, Assuit, Egypt 
that sedimentation has been regarded as one of the most important fluxes in aquatic systems (Asaolu et al., 1997; Zoumis et al., 2001). The release of trace metals from sediments into the water body and consequently to fish will depend on the speciation of metals and the physical and chemical characteristics of the aquatic system (Morgan and Stumm, 1991).

Fish have been the most popular choice as test organism and for monitoring aquatic toxicity because fish are often at the top of the aquatic food chain and may concentrate large amounts of some metals from the water. Accumulation patterns of contaminants in fish depend both on uptake and elimination rates (Hakanson, 1984). So, fish might prove a better media than water for detecting heavy metals contamination of freshwater ecosystem (Barak and Mason, 1990). Fish have been used for many years to determine the pollution status of water and are thus regarded as excellent biological marker of metals in aquatic ecosystem (Bahnasawy et al., 2009).

The need to make an adequate assessment of the level of heavy metal contamination in the environment has led to the initiation of several pollution monitoring programmes and research work. In Egypt, as in many other countries, the assessment of heavy metals levels in water, sediment and biotic resources in many natural water bodies has received considerable attention in the recent past (Ishii et al., 1985; Kareleeson-Norrgren et al., 1985; Olsson et al., 1988; Mohamed et al., 1990; Khallaf et al., 1994; Zaky, 1995; Gray et al., 1997; Chan et al., 1999; Osman and Kloas, 2010). However, the effects of seasons on metal concentrations in these matrices have not been adequately addressed. This study therefore focuses on the effects of seasons on the concentrations of $\mathrm{Pb}, \mathrm{Cd}, \mathrm{Cu}, \mathrm{Cr}$ and $\mathrm{Fe}$ in water, sediment and freshwater fish (Clarias gariepinus) collected from the whole course of the River Nile form it spring at Aswan to its estuaries at Damietta and Rosetta.

\section{MATERIALS AND METHODS}

Study area: Six sampling sites were selected along the whole course of the River Nile from its spring at Aswan to its estuaries at Rosetta and Damietta (Fig. 1).

Sampling: Water, sediment and tissues samples from the selected sites were sampled bimonthly from the main course of the River Nile during the period from July 2009 to June 2010. Water samples (108 samples) were collected by polyvinyl chloride Van Dorn water sampler $(5 \mathrm{~L}$ capacity) at $2 \mathrm{~m}$ depths. Sediment samples (108 samples) were collected by using Ekman burdge sampler and kept frozen until analyzed. Sampling and preservation of water

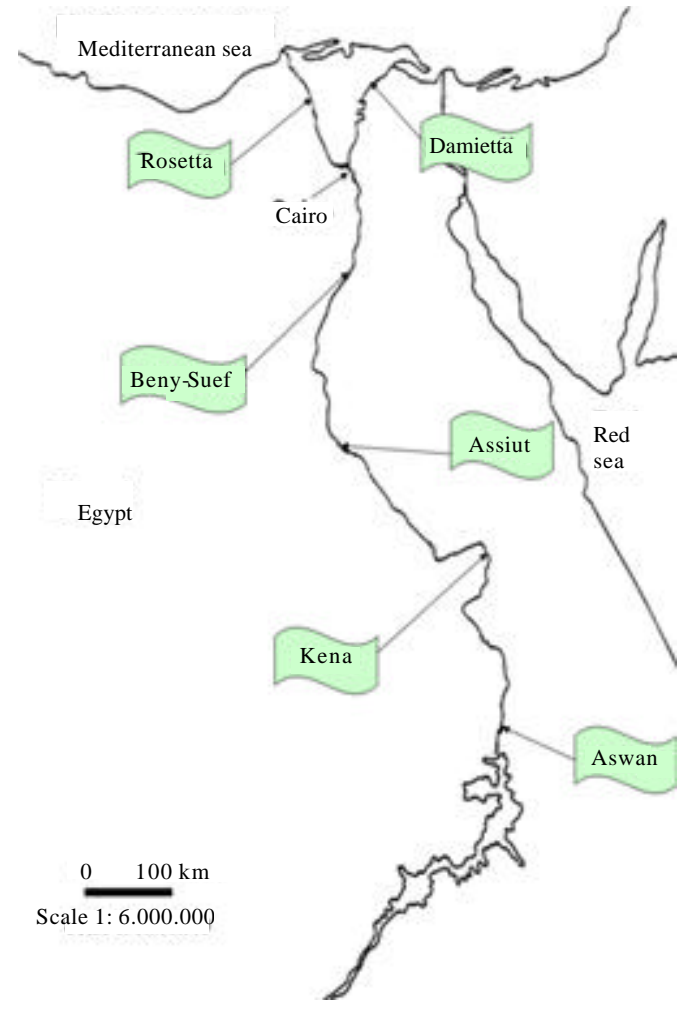

Fig. 1: Map showing the sampling sites along the whole course of the River Nile from its spring at Aswan to its estuaries at Damietta and Rosetta branches

and sediment samples were done according to the traditional manual methods (APHA, 1998). African catfish (Clarias gariepinus) were caught by gill net from the selected sites ( 72 specimens). The target organs (muscles, gills, gonads and liver) were excised and transported in liquid nitrogen container to the laboratory for chemical analysis.

Sample analysis: Total $\mathrm{Pb}, \mathrm{Cd}, \mathrm{Cu}, \mathrm{Cr}$ and $\mathrm{Fe}$ were measured in water samples after digestion using Graphite Furnace Atomic Absorption (GFAA) spectroscopy. A mixture of nitric acid and the material to be analysed was refluxed in a covered Griffin beaker. After the digestate has been brought to a low volume, it was cooled and brought up in dilute nitric acid $(3 \% \mathrm{v} / \mathrm{v})$. The sample was filtered, allowed settling and preparing it for analysis (APHA, 1998).

Sediment samples were allowed to defrost then air-dried in a circulating oven at $30^{\circ} \mathrm{C}$ and sieved mechanically using a $2 \mathrm{~mm}$ sieve. For the digestion of samples, $1 \mathrm{~g}$ sieved sediment was digested with repeated addition of nitric acid and hydrogen peroxide. For 
Graphite Furnace AA (GFAA) analysis, the resultant digestate was reduced in volume and then diluted to a final volume of $100 \mathrm{~mL}$. The elements of concern $(\mathrm{Pb}, \mathrm{Cd}$, $\mathrm{Cu}, \mathrm{Cr}$ and $\mathrm{Fe}$ ) in the samples were determined by Atomic Absorption Sectrophotometer (AAS).

About $1 \mathrm{~g}$ portions of fish tissues (muscles, gills, gonads and liver) were digested by means of a microwave after addition of nitric acid and hydrogen peroxide. The results were calculated in milligram per kilogram wet weight ( $\mathrm{mg} \mathrm{kg}^{-1}$ wet wt). Chemicals concentration were analysed according to German industrial standard, DIN 38406-6, (DEV, E6) with an Atomic Absorption Spectrometer using flame and graphite furnace technique. Mean concentrations of the selected heavy metals in water, sediment and tissues are shown in Table 1.

Statistical analysis: All values from chemical analyses were presented as mean $\pm \mathrm{SD}$. Data obtained from the experiment were subjected to one way Analysis of Variance (ANOVA) test using the Statistical Package for the Social Sciences. The correlation coefficients between heavy metals of water, sediments and tissues samples were calculated by the application of Pearson correlation analysis in order to indicate the nature and the sources of the polluting substances. In all cases, $\mathrm{p}<0.05$ was the accepted significance level.

\section{RESULTS AND DISCUSSION}

The concentrations of the selected heavy metals $(\mathrm{Pb}, \mathrm{Cd}, \mathrm{Cu}, \mathrm{Cr}$ and $\mathrm{Fe})$ in water, sediment and tissues of Clarias gariepinus are shown in Table 1. The highest concentrations of nearly all heavy metals were recorded in water, sediments and tissues samples collected from Rosetta and Damietta and the lowest ones were detected in the samples collected from Aswan and Kina (Table 1). For nearly all the detected heavy metals significant differences $(F=3.79, p<0.05)$ were detected between the selected sites. A significant $(\mathrm{p}<0.05)$ high correlation were observed between the concentrations of the selected heavy metals in water in sediment and in tissues of the African catfish (from 0.951-0.988).

The seasonal mean concentrations of the selected heavy metals $(\mathrm{Pb}, \mathrm{Cd}, \mathrm{Cu}, \mathrm{Cr}$ and $\mathrm{Fe})$ in water, sediments and tissues samples are shown in Table 2-4. The highest levels of the detected heavy metals were recorded in water and sediment samples collected during spring at nearly all sites. The lowest ones were recorded in water and sediment samples collected during autumn at all sites for most heavy metals (excluded $\mathrm{Cr}$ ). The lowest concentration of $\mathrm{Cr}$ was recorded in water and sediment samples collected during winter along the whole course of the River Nile (Table 2 and 3). Seasonal mean concentrations of the selected heavy metals in the tissues

Table 1: Mean concentration and SD of the selected heavy metals in water ( $\mathrm{ppm}$ ), sediment and tissues of Clarias gariepinus (mg kg ${ }^{-1}$ dry weight) collected from different localities along the whole course of the River Nile, Egypt

\begin{tabular}{|c|c|c|c|c|c|}
\hline \multirow[b]{2}{*}{ Localities } & \multicolumn{5}{|l|}{ Mean $\pm \mathrm{SD}$} \\
\hline & $\mathrm{Pb}$ & $\mathrm{Cd}$ & $\mathrm{Cu}$ & $\mathrm{Cr}$ & $\mathrm{Fe}$ \\
\hline \multicolumn{6}{|l|}{ Aswan } \\
\hline Water & $0.01 \pm 0.02$ & $0.004 \pm 0.004$ & $0.03 \pm 0.03$ & $0.003 \pm 0.003$ & $0.2 \pm 0.200$ \\
\hline Sediment & $3.1 \pm 2.700$ & $0.4 \pm 0.3$ & $0.03 \pm 0.03$ & $8.8 \pm 1.6$ & $397.1 \pm 291.9$ \\
\hline C. gariepinus & $7.4 \pm 3.400$ & $1.0 \pm 1.5$ & $14.6 \pm 2.700$ & $4.5 \pm 2.3$ & $47.6 \pm 11.50$ \\
\hline \multicolumn{6}{|l|}{ Kena } \\
\hline Water & $0.02 \pm 0.01$ & $0.002 \pm 0.002$ & $0.02 \pm 0.02$ & $0.01 \pm 0.01$ & $0.2 \pm 0.200$ \\
\hline Sediment & $3.1 \pm 2.300$ & $0.5 \pm 0.2$ & $0.02 \pm 0.02$ & $11.1 \pm 14.4$ & $379.4 \pm 238.6$ \\
\hline C. gariepinus & $7.4 \pm 3.400$ & $1.0 \pm 1.5$ & $14.6 \pm 2.700$ & $4.5 \pm 2.26$ & $47.6 \pm 11.50$ \\
\hline \multicolumn{6}{|l|}{ Assiut } \\
\hline Water & $0.02 \pm 0.02$ & $0.01 \pm 0.01$ & $0.03 \pm 0.03$ & $0.01 \pm 0.01$ & $0.3 \pm 0.300$ \\
\hline Sediment & $4.4 \pm 2.400$ & $0.6 \pm 0.4$ & $0.03 \pm 0.03$ & $17.6 \pm 24.9$ & $496.6 \pm 333.5$ \\
\hline C. gariepinus & $5.1 \pm 3.300$ & $0.7 \pm 0.4$ & $6.2 \pm 3.100$ & $4.5 \pm 2.9$ & $47.9 \pm 12.80$ \\
\hline \multicolumn{6}{|l|}{ Beny-suef } \\
\hline Water & $0.02 \pm 0.01$ & $0.002 \pm 0.002$ & $0.03 \pm 0.03$ & $0.02 \pm 0.01$ & $0.5 \pm 0.400$ \\
\hline Sediment & $11.5 \pm 11.60$ & $0.6 \pm 0.3$ & $0.03 \pm 0.03$ & $10.3 \pm 10.3$ & $536.4 \pm 351.2$ \\
\hline C. gariepinus & $5.3 \pm 4.100$ & $0.7 \pm 0.3$ & $7.7 \pm 2.600$ & $4.0 \pm 2.7$ & $94.4 \pm 20.50$ \\
\hline \multicolumn{6}{|l|}{ Damietta } \\
\hline Water & $0.03 \pm 0.04$ & $0.02 \pm 0.02$ & $0.03 \pm 0.03$ & $0.1 \pm 0.1$ & $0.4 \pm 0.300$ \\
\hline Sediment & $6.9 \pm 4.900$ & $0.7 \pm 0.4$ & $0.03 \pm 0.03$ & $9.1 \pm 11.6$ & $632.1 \pm 393.8$ \\
\hline C. gariepinus & $12.9 \pm 3.810$ & $1.03 \pm 0.41$ & $6.1 \pm 4.800$ & $5.4 \pm 2.8$ & $89.8 \pm 32.50$ \\
\hline \multicolumn{6}{|l|}{ Rosetta } \\
\hline Water & $0.1 \pm 0.100$ & $0.01 \pm 0.02$ & $0.1 \pm 0.030$ & $0.1 \pm 0.2$ & $0.5 \pm 0.500$ \\
\hline Sediment & $46.9 \pm 23.50$ & $0.7 \pm 0.5$ & $0.1 \pm 0.030$ & $8.7 \pm 8.4$ & $698.7 \pm 287.2$ \\
\hline C. gariepinus & $15.1 \pm 8.100$ & $1.1 \pm 0.6$ & $13.1 \pm 4.600$ & $7.2 \pm 2.7$ & $95.9 \pm 27.40$ \\
\hline
\end{tabular}


Environ. Res. J., 6 (5): 321-328, 2012

Table 2: Mean seasonal variations of the selected heavy metals $(\mathrm{ppm})$ in water samples collected from different localities along the whole course of the River

\begin{tabular}{|c|c|c|c|c|c|c|}
\hline \multirow[b]{2}{*}{ Seasons } & \multicolumn{6}{|l|}{ Mean \pm SD } \\
\hline & Aswan & Kena & Assiut & Beny-Suef & Damietta & Rosetta \\
\hline \multicolumn{7}{|l|}{$\mathbf{P b}$} \\
\hline Winter & $0.03 \pm 0.02$ & $0.01 \pm 0.03$ & $0.01 \pm 0.01$ & $0.03 \pm 0.01$ & $0.06 \pm 0.02$ & $0.1 \pm 0.04$ \\
\hline Spring & $0.03 \pm 0.02$ & $0.03 \pm 0.01$ & $0.02 \pm 0.01$ & $0.03 \pm 0.01$ & $0.09 \pm 0.04$ & $0.1 \pm 0.04$ \\
\hline Summer & $0.01 \pm 0.02$ & $0.02 \pm 0.01$ & $0.02 \pm 0.01$ & $0.02 \pm 0.01$ & $0.04 \pm 0.02$ & $0.03 \pm 0.01$ \\
\hline Autumn & $0.01 \pm 0.01$ & $0.01 \pm 0.01$ & $0.01 \pm 0.01$ & $0.01 \pm 0.01$ & $0.01 \pm 0.01$ & $0.01 \pm 0.002$ \\
\hline \multicolumn{7}{|l|}{$\mathrm{Cd}$} \\
\hline Winter & $0.002 \pm 0.0004$ & $0.002 \pm 4.7$ & $0.003 \pm 6.5$ & $0.002 \pm 0.001$ & $0.01 \pm 0.01$ & $0.003 \pm 0.001$ \\
\hline Spring & $0.01 \pm 0.004$ & $0.01 \pm 0.001$ & $0.01 \pm 0.01$ & $0.003 \pm 0.002$ & $0.01 \pm 0.01$ & $0.03 \pm 0.02$ \\
\hline Summer & $0.002 \pm 0.002$ & $0.002 \pm 0.003$ & $0.001 \pm 0.001$ & $0.004 \pm 40.001$ & $0.01 \pm 0.01$ & $0.03 \pm 0.004$ \\
\hline Autumn & $0.001 \pm 0.002$ & $0.003 \pm 0.001$ & $0.001 \pm 0.01$ & $0.003 \pm 0.004$ & $0.01 \pm 0.01$ & $0.002 \pm 0.001$ \\
\hline \multicolumn{7}{|l|}{$\mathrm{Cu}$} \\
\hline Winter & $0.01 \pm 0.04$ & $0.03 \pm 0.03$ & $0.03 \pm 0.02$ & $0.1 \pm 0.03$ & $0.1 \pm 0.03$ & $0.1 \pm 0.1$ \\
\hline Spring & $0.04 \pm 0.03$ & $0.04 \pm 0.02$ & $0.07 \pm 0.02$ & $0.1 \pm 0.1$ & $0.1 \pm 0.01$ & $0.1 \pm 0.02$ \\
\hline Summer & $0.003 \pm 0.001$ & $0.01 \pm 0.004$ & $0.01 \pm 0.002$ & $0.01 \pm 0.01$ & $0.02 \pm 0.02$ & $0.1 \pm 0.02$ \\
\hline Autumn & $0.03 \pm 0.01$ & $0.03 \pm 0.02$ & $0.04 \pm 0.02$ & $0.04 \pm 0.02$ & $0.03 \pm 0.03$ & $0.1 \pm 0.01$ \\
\hline \multicolumn{7}{|l|}{$\mathrm{Cr}$} \\
\hline Winter & $0.002 \pm 0.001$ & $0.004 \pm 0.001$ & $0.01 \pm 0.001$ & $0.01 \pm 0.001$ & $0.01 \pm 0.001$ & $0.01 \pm 0.001$ \\
\hline Spring & $0.02 \pm 0.004$ & $0.02 \pm 0.01$ & $0.04 \pm 0.01$ & $0.02 \pm 0.01$ & $0.04 \pm 0.02$ & $0.04 \pm 0.01$ \\
\hline Summer & $0.01 \pm 0.001$ & $0.01 \pm 0.01$ & $0.02 \pm 0.004$ & $0.01 \pm 0.003$ & $0.01 \pm 0.02$ & $0.04 \pm 0.1$ \\
\hline Autumn & $0.004 \pm 0.001$ & $0.004 \pm 0.001$ & $0.02 \pm 0.001$ & $0.03 \pm 0.002$ & $0.07 \pm 0.02$ & $0.02 \pm 0.1$ \\
\hline \multicolumn{7}{|l|}{$\mathrm{Fe}$} \\
\hline Winter & $0.4 \pm 0.2$ & $0.3 \pm 0.22$ & $0.5 \pm 0.11$ & $0.5 \pm 0.5$ & $0.4 \pm 0.3$ & $0.3 \pm 0.1$ \\
\hline Spring & $0.5 \pm 0.1$ & $0.6 \pm 0.3$ & $0.7 \pm 0.1$ & $1.0 \pm 0.7$ & $0.9 \pm 0.2$ & $2.2 \pm 1.9$ \\
\hline Summer & $0.3 \pm 0.1$ & $0.2 \pm 0.04$ & $0.4 \pm 0.03$ & $0.6 \pm 0.1$ & $0.6 \pm 0.2$ & $0.7 \pm 0.02$ \\
\hline Autumn & $0.1 \pm 0.1$ & $0.2 \pm 0.2$ & $0.4 \pm 0.1$ & $0.4 \pm 0.6$ & $0.4 \pm 0.1$ & $0.3 \pm 0.2$ \\
\hline
\end{tabular}

Table 3: Mean seasonal variations of the selected heavy metals ( $\mathrm{mg} \mathrm{kg}^{-1}$ dry weight) in sediments samples collected from different localities along the whole course of the River Nile, Egypt Mean \pm SD

\begin{tabular}{|c|c|c|c|c|c|c|}
\hline \multirow[b]{2}{*}{ Seasons } & \multicolumn{6}{|l|}{ Mean \pm SD } \\
\hline & Aswan & Kena & Assiut & Beny-suef & Damietta & Rosetta \\
\hline \multicolumn{7}{|l|}{$\mathrm{Pb}$} \\
\hline Winter & 2. $6 \pm 1.400$ & $3.8 \pm 3.5$ & $3.9 \pm 3.500$ & $15.3 \pm 8.500$ & $10.7 \pm 3.800$ & $21.2 \pm 9.700$ \\
\hline Spring & $6.8 \pm 4.010$ & $7.8 \pm 1.6$ & $5.4 \pm 2.700$ & $13.3 \pm 2.150$ & $14.9 \pm 7.500$ & $27.6 \pm 9.700$ \\
\hline Summer & $4.1 \pm 1.100$ & $3.9 \pm 1.9$ & $3.4 \pm 1.600$ & $4.4 \pm 3.100$ & $7.4 \pm 3.100$ & $21.1 \pm 11.30$ \\
\hline Autumn & $1.6 \pm 0.600$ & $1.9 \pm 0.3$ & $1.8 \pm 1.800$ & $6.7 \pm 6.900$ & $4.8 \pm 1.700$ & $11.7 \pm 6.100$ \\
\hline \multicolumn{7}{|l|}{ Cd } \\
\hline Winter & $0.7 \pm 0.600$ & $0.7 \pm 0.4$ & $0.5 \pm 0.100$ & $0.4 \pm 0.400$ & $0.4 \pm 0.100$ & $0.2 \pm 0.100$ \\
\hline Spring & $0.7 \pm 0.400$ & $0.8 \pm 0.3$ & $0.9 \pm 0.200$ & $0.9 \pm 0.300$ & $1.4 \pm 0.200$ & $1.3 \pm 0.500$ \\
\hline Summer & $0.2 \pm 0.100$ & $0.4 \pm 0.1$ & $0.9 \pm 0.200$ & $1.1 \pm 0.600$ & $1.4 \pm 0.100$ & $1.2 \pm 0.300$ \\
\hline Autumn & $0.3 \pm 0.100$ & $0.4 \pm 0.02$ & $0.7 \pm 0.100$ & $0.6 \pm 0.200$ & $0.6 \pm 0.100$ & $0.4 \pm 0.030$ \\
\hline \multicolumn{7}{|l|}{$\mathrm{Cu}$} \\
\hline Winter & $9.4 \pm 3.400$ & $13.9 \pm 4.4$ & $17.2 \pm 1.200$ & $14.7 \pm 4.100$ & $26.5 \pm 5.040$ & $38.7 \pm 3.800$ \\
\hline Spring & $16.8 \pm 5.300$ & $17.7 \pm 6.8$ & $17.7 \pm 6.500$ & $15.8 \pm 8.100$ & $26.8 \pm 6.800$ & $32.9 \pm 13.70$ \\
\hline Summer & $15.3 \pm 3.100$ & $13.4 \pm 5.6$ & $11.5 \pm 2.800$ & $10.5 \pm 2.400$ & $18.9 \pm 4.040$ & $22.01 \pm 7.60$ \\
\hline Autumn & $8.9 \pm 4.700$ & $9.7 \pm 6.2$ & $11.1 \pm 0.600$ & $6.9 \pm 2.700$ & $22.1 \pm 2.500$ & $18.6 \pm 10.70$ \\
\hline \multicolumn{7}{|l|}{$\mathrm{Cr}$} \\
\hline Winter & $2.8 \pm 1.400$ & $0.6 \pm 0.5$ & $1.8 \pm 0.800$ & $4.8 \pm 2.800$ & $8.4 \pm 4.400$ & $9.6 \pm 1.700$ \\
\hline Spring & $11.7 \pm 2.600$ & $8.6 \pm 2.6$ & $5.1 \pm 1.300$ & $12.8 \pm 4.100$ & $18.1 \pm 0.400$ & $19.4 \pm 5.100$ \\
\hline Summer & $8.4 \pm 2.900$ & $7.6 \pm 1.02$ & $12.9 \pm 3.800$ & $10.2 \pm 2.700$ & $17.2 \pm 1.800$ & $18.9 \pm 2.700$ \\
\hline Autumn & $8.1 \pm 3.300$ & $5.4 \pm 0.9$ & $7.1 \pm 3.700$ & $8.9 \pm 2.400$ & $16.5 \pm 2.300$ & $17.3 \pm 3.600$ \\
\hline \multicolumn{7}{|l|}{$\mathrm{Fe}$} \\
\hline Winter & $331.6 \pm 152.2$ & $451.02 \pm 124.5$ & $638.6 \pm 28.50$ & $807.5 \pm 65.30$ & $867.04 \pm 134.4$ & $971.1 \pm 24.10$ \\
\hline Spring & $508.2 \pm 143.8$ & $556.7 \pm 75.8$ & $559.6 \pm 188.8$ & $839.6 \pm 56.30$ & $866.5 \pm 171.40$ & $891.1 \pm 132.9$ \\
\hline Summer & $440.7 \pm 32.30$ & $408.7 \pm 95.2$ & $405.3 \pm 53.20$ & $393.2 \pm 104.5$ & $475.2 \pm 42.100$ & $516.9 \pm 54.30$ \\
\hline Autumn & $349.3 \pm 49.20$ & $311.1 \pm 49.5$ & $457.4 \pm 121.8$ & $496.9 \pm 78.30$ & $515.7 \pm 47.200$ & $529.4 \pm 61.90$ \\
\hline
\end{tabular}

of the African catfish exhibited their highest concentration during summer at nearly all sites. The lowest levels of these heavy metals were recorded in the tissues sampled during winter and/or autumn depending on the sampling site (Table 4).
The contamination of sediments, water and biota with heavy metals is of important concern because of their toxicity, persistence and bio-accumulative nature (Ikem et al., 2003). Generally, the natural sources of heavy metals in coastal waters are through land, heavy fresh 
Environ. Res. J., 6 (5): 321-328, 2012

Table 4: Mean seasonal variations of the selected heavy metals ( $\mathrm{mg} \mathrm{kg}^{-1}$ dry weight) in tissues samples of Clarias gariepinus collected from different localities along the whole course of the River Nile, Egypt Mean \pm SD

\begin{tabular}{|c|c|c|c|c|c|c|}
\hline$\underline{\text { Seasons }}$ & Aswan & Kena & Assiut & Beny-Suef & Damietta & Rosetta \\
\hline \multicolumn{7}{|l|}{$\mathrm{Pb}$} \\
\hline Winter & $8.6 \pm 3.30$ & $3.3 \pm 2.60$ & $2.3 \pm 1.90$ & $2.04 \pm 1.9$ & $14.7 \pm 2.50$ & $17.6 \pm 4.400$ \\
\hline Spring & $4.9 \pm 2.90$ & $2.8 \pm 1.50$ & $3.2 \pm 1.60$ & $7.4 \pm 1.40$ & $11.6 \pm 1.70$ & $16.3 \pm 6.500$ \\
\hline Summer & $9.3 \pm 1.80$ & $7.3 \pm 0.80$ & $7.9 \pm 2.60$ & $7.4 \pm 2.60$ & $14.9 \pm 1.60$ & $18.5 \pm 1.600$ \\
\hline Autumn & $9.03 \pm 2.7$ & $6.9 \pm 2.40$ & $7.7 \pm 1.30$ & $7.1 \pm 4.10$ & $14.4 \pm 1.20$ & $17.9 \pm 8.600$ \\
\hline \multicolumn{7}{|l|}{ Cd } \\
\hline Winter & $0.5 \pm 0.30$ & $0.6 \pm 0.20$ & $0.3 \pm 0.20$ & $0.4 \pm 0.20$ & $0.5 \pm 0.20$ & $0.6 \pm 0.100$ \\
\hline Spring & $0.2 \pm 0.20$ & $0.6 \pm 0.20$ & $1.01 \pm 0.1$ & $1.0 \pm 0.10$ & $1.04 \pm 0.6$ & $1.7 \pm 0.800$ \\
\hline Summer & $2.2 \pm 0.70$ & $1.0 \pm 0.40$ & $1.08 \pm 0.3$ & $1.1 \pm 0.20$ & $1.2 \pm 0.30$ & $1.9 \pm 0.300$ \\
\hline Autumn & $0.5 \pm 0.30$ & $0.7 \pm 0.20$ & $0.5 \pm 0.20$ & $0.4 \pm 0.20$ & $1.0 \pm 0.20$ & $0.8 \pm 0.400$ \\
\hline \multicolumn{7}{|l|}{$\mathrm{Cu}$} \\
\hline Winter & $7.4 \pm 2.90$ & $3.9 \pm 3.40$ & $7.4 \pm 2.30$ & $8.4 \pm 2.20$ & $5.7 \pm 3.80$ & $11.04 \pm 9.50$ \\
\hline Spring & $6.9 \pm 3.80$ & $4.9 \pm 2.10$ & $6.7 \pm 2.70$ & $7.7 \pm 3.40$ & $7.03 \pm 2.9$ & $11.0 \pm 5.500$ \\
\hline Summer & $8.6 \pm 2.90$ & $7.6 \pm 6.40$ & $9.6 \pm 2.10$ & $9.9 \pm 3.70$ & $11.9 \pm 3.40$ & $16.02 \pm 12.1$ \\
\hline Autumn & $4.3 \pm 3.10$ & $2.3 \pm 2.10$ & $3.5 \pm 1.20$ & $6.2 \pm 4.50$ & $2.6 \pm 2.80$ & $14.8 \pm 16.70$ \\
\hline \multicolumn{7}{|l|}{$\mathrm{Cr}$} \\
\hline Winter & $4.8 \pm 1.80$ & $3.3 \pm 2.10$ & $1.8 \pm 0.70$ & $2.2 \pm 0.60$ & $4.04 \pm 0.9$ & $7.0 \pm 1.900$ \\
\hline Spring & $5.2 \pm 1.04$ & $5.0 \pm 2.40$ & $3.1 \pm 2.20$ & $2.4 \pm 1.90$ & $4.8 \pm 2.60$ & $6.7 \pm 3.800$ \\
\hline Summer & $5.7 \pm 1.40$ & $8.2 \pm 0.90$ & $6.4 \pm 1.80$ & $5.4 \pm 2.40$ & $7.9 \pm 5.30$ & $7.6 \pm 3.300$ \\
\hline Autumn & $5.0 \pm 2.40$ & $6.9 \pm 0.50$ & $4.7 \pm 0.80$ & $4.2 \pm 1.20$ & $4.1 \pm 1.40$ & $7.7 \pm 1.200$ \\
\hline \multicolumn{7}{|l|}{$\mathrm{Fe}$} \\
\hline Winter & $40.6 \pm 9.04$ & $43.0 \pm 10.9$ & $43.6 \pm 15.9$ & $94.3 \pm 20.7$ & $83.0 \pm 24.1$ & $81.9 \pm 17.10$ \\
\hline Spring & $55.2 \pm 16.1$ & $67.1 \pm 10.8$ & $55.6 \pm 19.5$ & $112.8 \pm 10.1$ & $93.7 \pm 50.2$ & $101.9 \pm 38.30$ \\
\hline Summer & $56.4 \pm 19.9$ & $68.7 \pm 16.9$ & $55.8 \pm 12.1$ & $114.3 \pm 28.9$ & $99.1 \pm 50.3$ & $111.2 \pm 33.90$ \\
\hline Autumn & $42.4 \pm 12.9$ & $52.2 \pm 10.5$ & $38.4 \pm 9.90$ & $90.3 \pm 9.80$ & $81.9 \pm 22.1$ & $92.4 \pm 19.60$ \\
\hline
\end{tabular}

water inflow, agricultural waste, aquaculture discharge and river run off and the mechanical and chemical weathering of rocks (Ashokkumar et al., 2009). Also, the components washed from the atmosphere through rainfall, windblown dust, forest fires and volcanic particles add to the distribution of heavy metals in water (Bryan, 1984). The detailed investigation (Osman and Kloas, 2010) of water quality assessment along the whole course of the River Nile concluded higher mean concentrations of nearly all the detected heavy metals in water, sediment and tissues samples collected from sampling sites downstream River Nile compared to those collected from upstream River Nile. The levels of such metals were significantly $(\mathrm{p}<0.05)$ increased from the spring of the River Nile at Aswan toward its estuaries at Damietta and Rosetta sites. Such increase proves the presence of large quantities of organic and inorganic pollutants in Rosetta and Damietta water. This finding was expected due to the fact that the level of contamination is greater downstream River Nile, compared to upstream sampling sites where more domestic and industrial effluents have been released into the Nile without adequate treatment (Osman and Kloas, 2010). Fine grain particles in sediment usually act as effective collectors and carriers of dissolved metals from the water column to the sediments and thus elevate concentration of heavy metals in sediment (Chouba et al., 2007). Metal levels in sediment samples were higher than those in surface water and fish samples collected from the same sites and at the same sampling time (Osman and
Kloas, 2010). The latter study has confirmed that sediments are important hosts for toxic metals. It has been shown that sediment permit the detection of heavy metals that may be either absent or in low concentration in water column.

The highest mean concentrations of the selected heavy metals in water and sediment samples were recorded during spring period along the whole course of the River Nile. The lowest ones were recorded during autumn for nearly all heavy metals. Such variations were depending on the surrounding industrial and agriculture activities. The increase of heavy metals levels during spring proves the presence of higher industrial and agricultural activities during this period along the whole course of the River Nile. Also, increasing anthropogenic activities along the Nile might certainly have a significant effect on metal concentration in the coastal waters of some sites. Significant $(\mathrm{p}<0.05)$ seasonal mean levels among sites were recorded indicating the lack of uniformity of their distribution. This can be attributed to the different pollution levels at the studied sites and to the differences in water chemistry at such sites. The fluctuation in heavy metals seasonal variations among sites depends not only on the total concentration in water and sediment but also on the soil or sediment properties, metal properties and environmental factors.

Fish surviving at highly polluted areas accumulate higher levels of heavy metals than those surviving at less polluted area of the same lake (Bahnasawy et al., 2009). In 
the present research, mean levels of the selected heavy metals in the tissues of African catfish follow the same pattern as in water and sediment in being higher at Damietta and Rosetta. This indicated a close correlation between the concentration of metals in water and in fish. Such correlation was proved in the present research by the application of Pearson correlation analysis which exhibited high significant correlation (from 0.951-0.988) between the concentrations of the selected heavy metals in water in sediment and in tissues of the African catfish. Fish has been reported to accumulate metals from water by diffusion via skin and gills as well as oral consumption/drinking of water (Nussey et al., 2000; Oguzie, 2003; Osman et al., 2010). Knowledge of heavy metal concentrations in fish is important with respect to nature of management and human consumption of fish (Osman and Kloas, 2010). The previous research (Osman and Kloas, 2010) concluded that heavy metal residues in the tissues of Clarias gariepinus exhibited different patterns of accumulation and distribution among the selected tissues and localities. It was evident from such study that liver was the site of maximum accumulation for the elements followed by gills while muscle was the over all site of least metal accumulation. The low accumulation of metals in muscle is particularly important because muscles contribute the greatest mass of the flesh that is consumed as food (Osman and Kloas, 2010).

The seasonal variations of heavy metals in fish were reported by many researchers (Hamza-Chaffai et al., 1996; Khallaf et al., 1998; Ibrahim et al., 1999). In the present study, the levels of heavy metals in the tissues of fish showed highly significant differences between seasons. The maximum level of nearly all the selected heavy metals were recorded in the tissues of fish sampled during summer along the whole course of the River Nile. The highest metal levels in the tissues of fish during summer were followed in the present study by a remarkable DNA damages in the tissues of African catfish sampled during summer period (Osman et al., 2011). The lowest metals levels were recoded in fishes collected during winter and/or autumn at all sites examined which corresponding less industrial and agricultural activities along the Nile course. The rate of accumulation and the ability of the tissues to detoxify particular metals also differ greatly. The concentrations of the selected heavy metals present are dependent on the anthropogenic input into the Nile. This would disrupt a sinusoidal curve pattern. The results of the present study suggested that seasonal variation of heavy-metal levels in the tissues of African catfish Clarias gariepinus collected from the River Nile was follow sinusoidal curves. The maximum level of most heavy metals was detected during summer which represent the growth period of the African catfish.
Borchardt et al. (1988) suggested that seasonal variations of metal levels in $M$. edulis follow a growth period in late spring/early summer causes rapid increases in biomass which results in lower metal levels when they are expressed in relation to this increased biomass. Accumulation and elimination of metals are also affected by spawning (O'Leary and Breen, 1998). If these metals are stored in the gonad tissue they may be eliminated from the tissue during spawning. According to Van Oordt et al. (1987) the spawning season of C. gariepinus extended between May and August. Thus, some of the recorded changes in metal levels in the tissues of C. gariepinus can be attributed to spawning and/or to anthropogenic influences. Accordingly, the minimum level of most metals was recorded during autumn period which correspond the breeding season of Clarias gariepinus. Ansari et al. (2004) reported that variations of the metals concentration at given site may be often be due to seasonal changes of the organisms tissues weight rather than to any variability in the absolute metal content of the organism.

\section{CONCLUSION}

Generally, the increase in heavy metals concentrations in the Nile water and sediment during spring period might be attributed to the direct inputs from different sources (industrial and agricultural wastes). Most of the factories along the Nile course research annually during the period from December to June reaching to their maximum capacity during March (spring). Also, the agricultural activities increase during spring period which led to a remarkable increase of the agricultural discharges into the River Nile. In addition, the increase in density of boats and ship during spring which discharge its effluent directly to the Nile containing high amount of $\mathrm{Pb}$ in both the dissolved and particular phases.

\section{ACKNOWLEDGEMENTS}

This research was supported by Science and Technology development fund (Project ID 448). Researcher would like to thank Mr. Mohamed Nassar, Alaa Mustafa, Arfah Khodary, Said Hanfy, Khabab Mostafa, Mohsen Yousef and shrief Aboeldahb for their support during sampling and analysis processes. Parts of this study were conducted during 2010-2012 in the framework of an Alexander von Humboldt foundation postdoctoral fellowship for the first researcher (3.4AGY/1134716 STP), hosted by Leibniz-Institute of Freshwater Ecology and Inland Fisheries, Berlin, Germany. 


\section{REFERENCES}

APHA, 1998. Standard Methods for the Examination of Waters and Wastewaters. 20th Edn., American Public Health Association (APHA), Washington, DC., USA.

Ansari, T.M., I.L. Marr and N. Tariq, 2004. Heavy metals in marine pollution perspective-a mini review. J. Applied Sci., 4: 1-20.

Asaolu, S.S., K.O. Ipinmoroti, O. Olaofe and C.E. Adeeyinwo, 1997. Seasonal variation in heavy metal distribution in sediments from Ondo State Coastal area. Ghana J. Chem., 3: 11-14.

Ashokkumar, S., P. Mayavu, P. Sampathkumar, P. Manivasagam and G. Rajaram, 2009. Seasonal distribution of heavy metals in the mullipallam creek of muthupettai mangroves (Southeast Coast of India). Am. Eurasian J. Sci. Res., 4: 308-31 2.

Bahnasawy, M., A.A. Khidr and N. Dheina, 2009. Seasonal variations of heavy metals concentrations in mullet, Mugil cephalus and Liza ramada (Mugilidae) from Lake Manzala, Egypt. Applied Sci. Res., 5: 845-852.

Barak, N.A. and C.F. Mason, 1990. Mercury, cadmium and lead in eels and roach: The effects of size, season and locality on metal concentrations in flesh and liver. Sci. Total Environ., 82: 249-256.

Borchardt, T., S. Burchert, H. Hablizel, L. Karbe and R. Zeitner, 1988. Trace metal concentrations in mussels: Comparison between estuarine, coastal and offshore regions in the Southern North Sea from 1983-1986. Mar. Ecol. Prog. Ser., 42: 17-31.

Bruins, M.R., S. Kapil and F.W. Oehme, 2000. Microbial resistance to metals in the environment. Ecotoxicol. Environ. Safety, 45: 198-207.

Bryan, G.W., 1984. Pollution Due to Heavy Metals and their Compounds. In: Marine Ecology, Kinne, O. (Ed.). John Wiley and Sons, New York, USA., ISBN-13: 9780471902164, pp: 1289-1431.

Chan, H.M., M. Trifonopoulos, A. Ing, O. Receveur and E. Johnson, 1999. Consumption of freshwater fish in Kahnawake: Risks and benefits. Environ. Res., 80: S213-S222.

Chouba, L., M. Kraiem, W. Njimi, C.H. Tissaoui, J.R. Thompson and R.J. Flower, 2007. Seasonal variation of heavy metals ( $\mathrm{Cd}, \mathrm{Pb}$ and $\mathrm{Hg}$ ) in sediments and in mullet, Mugil cephalus (Mugilidae), from the Ghar El Melh Lagoon (Tunisia). Waters Bull., 4: 45-52.

Fagbemi, T.N. and A.A. Oshodi, 1991. Chemical composition and functional properties of full-fat fluted pumpkin seed flour (Telfairia occidentalis). Nig. Food J., 9: 26-32.
Forstner, U. and G.T.W. Wittman, 1981. Metal Pollution in Aquatic Environment. Spring-Verlag, New York, USA., Pages: 386.

Gray, N.D., R.W. Pickup, J.G. Jones and I.M. Head, 1997. Ecophysiological evidence that achromatium oxaliferum is responsible for the oxidation of reduced sulfur species to sulfate in a freshwater sediment. Applied Environ. Microbiol., 63: 1905-1910.

Haiyan, W. and A.O. Stuanes, 2003. Heavy metal pollution in air-water-soil-plant system of zhuzhou city, hunan province, china. Water Air Soil Pollut., 147: 79-107.

Hakanson, L., 1984. Metals in fish and sediment from the river kolbacksan water system, sweden Arch. Hydrobiol., 101: 373-400.

Hamza-Chaffai, A., M. Romeo and A. El-Abed, 1996. Heavy metals in different fishes from the middle Eastern Coast of Tunisia. Bull. Environ. Contam. Toxicol., 56: 766-773.

Hussein, H., S. Farag, K. Kandil and H. Moawad, 2005. Tolerance and uptake of heavy metals by Pseudomonads. Process Biochem., 40: 955-961.

Ibrahim, A., M. Bahnasawy, S. Mansy and R. El-Fayomy, 1999. Heavy metal accumulation in water, sediment and some fishes in Lake Manzala, Egypt. J. Egypt. Ger. Soc. Zool., 29: 43-58.

Idodo-Umeh, G., 2002. Pollution assessments of olomoro waterbodies using physical chemical and biological indices Ph.D. Thesis, University of Benin City, Nigeria, pages: 485.

Ikem, A., N.O. Egiebog and K. Nyavor, 2003. Trace Elements in water, fish and sediment from Tuskegee Lake, Southeastern USA. Water, Air Soil Pollut., 149: 51-75.

Ishii, T., R. Nakanara, M. Ishikawa and T. Koyanagi, 1985. Determination and distribution of trace elements in marine invertebrates. Bull. Jpn. Soc. Sci. Fish., 51: 609-617.

Kakulu, S.E. and O. Osibanjo, 1988. Trace heavy metal pollutional studies in sediments of the Niger delta area of Nigeria. J. Chem. Soc. Niger., 13: 9-15.

Kareleeson-Norrgren, L., P. Rumn and L. Forlin, 1985. Cadmium-included changes in gill morphology of zebra fish, brachydanio rebio (hamilton-buchanan) and rainbow trout J. Fish. Biol., 27: 81-95.

Khallaf, E.A., M. Galal and M. Authuman, 1998. Assessment of heavy metals pollution and their effects on Oreochromis niloticus in aquatic drainage water. J. Egypt German Soc. Zool., 26: 39-74.

Khallaf, M.F., F.G. Neverty and T.R. Tonkhy, 1994. Heavy metal concentration in fish and water of the river Nile and fish farms. Proceedings of the National Conference on the River Nile, December 10-14, 1994 , Assiut University, Egypt, pp: 35-42. 
Klavins, M., A. Briede, V. Rodinov, I. Kokorite, E. Parele and I. Klavina, 2000. Heavy metals in rivers of latvia. Sci. Total Environ., 262: 175-184.

Mohamed, A.E., R.M. Awadallah and S.A. Gaber, 1990. Chemical and ecological studies on tilapia nilotica Water SA., 16: 131-134.

Morgan, J.J. and W. Stumm, 1991. Chemical Processes in the Environment, Relevance of Chemical Speciation. In: Metals and their Compounds in the Environment: Occurrence, Analysis and Biological Relevance, Merian, E. (Ed.). 2nd Edn. Wiley-VCH, New York, USA., ISBN-13: 9780895735621 , Pages: 67.

Nussey, G., J.H.J. van Vuren and H.H. du Preez, 2000. Bioaccumulation of chromium, manganese, nickel and lead in the tissues of the moggel, Labeo umbratus (Cyprinidae), from Witbank Dam, Mpumalanga. Water S A, 26: 269-284.

O'Leary, C. and J. Breen, 1998. Seasonal variation of heavy metals in Mytilus edulis, Fucus vesiculosus and sediment from the Shannon estuary. Biol. Environ., 98: 153-169.

Oguzie, F., 2003. Distribution of heavy metals in water and sediments of the lower Ikpoba-river, Benin city, Nigeria. Pak. J. Sci. Ind. Res., 46: $156-160$.

Olsson, P.E., A. Larsson and C. Haux, 1988. Metallothionein and heavy metal levels in rainbow trout and Salmo gairdneri, during exposure to cadmium in water. Mar. Environ. Res., 24: 151-153.
Osman, A.G.M., A.E.B.M. Abd El Reheem, K.Y. AbuelFadl, A.G.G. El-Rab, 2010. Enzymatic and histopathologic biomarkers as indicators of aquatic pollution in fishes. Nat. Sci., 2: 1302-1311.

Osman, A.G.M., A.E.B.M. Abd El Reheem, M.A. Moustafa, U.M. Mahmoud, K.Y. Abuel-Fadl and W. Kloas, 2011. In situ evaluation of the genotoxic potential of the river Nile: I. Micronucleus and nuclear lesion tests of erythrocytes of Oreochromis niloticus niloticus (Linnaeus, 1758) and Clarias gariepinus (Burchell, 1822). Toxicol. Environ. Chem., 93: 1002-1017.

Osman, A.M. and W. Kloas, 2010. Water quality and heavy metal monitoring in water, sediments and tissues of the african catfish Clarias gariepinus (Burchell, 1822) from the river Nile, Egypt. Environ. Prot., 1: 389-400.

Suzuki, K.T., H. Sunaga, Y. Aoki, S. Hatakeyama, Y. Sumi and T. Suzuki, 1988. Binding of cadmium and copper in the mayfly Baetis thermicus larvae that inhabit in a river polluted with heavy metals. Comp. Biochem. Physiol., 91: 487-492.

Van Oordt, P.G.W.J., J. Peute, R. van Den Hurk and W.J.A.R. Viveen, 1987. Annual correlative changes in gonads and pituitary gonadotropes of feral African catfish, Clarias gariepinus. Aquacult. Asia, 63: $27-41$.

Zaky, Z.M., 1995. Lead pollution in upper egypt (1991-1995) in 1st intern Research Sci., 35: 129-150.

Zoumis, T., A. Schmidt, L. Grigorova and W. Calmano, 2001. Contaminants in sediments: Remobilisation and demobilisation. Sci. Total Environ., 266: 195-202. 